\title{
KINEZITERAPIJA GYDANT NUDEGIMŲ TRAUMAS. LITERATŪROS APŽVALGA
}

\author{
Brigita Siparytė-Sinkevičiené $\dot{e}^{1,2}$, Rytis Rimdeika ${ }^{1,2}$ \\ Lietuvos sveikatos mokslu universiteto ligonine Kauno klinikos ${ }^{1}$ \\ Lietuvos sveikatos mokslu universiteto Medicinos akademija ${ }^{2}$
}

\section{SANTRAUKA}

Tyrimo pagrindimas. Sergamumas nudegimais susijęs su ilgu gydymo laikotarpiu ir negalia. Nudegimų trauma dèl hipermetabolinio atsako pažeidžia daugelį organizmo funkcijų ir pasireiškia raumenų masès ir raumenų jègos sumažèjimu, kontraktūrų išsivystymu. Nustatyta, kad kineziterapijos taikymas didina fizinį pajëgumą, raumenų jègą, gerina kūno kompoziciją ir gyvenimo pilnatvę.

Tikslas - išanalizuoti mokslinę literatūrą apie nudegimų traumos poveikị ịvairioms organizmo sistemoms ir kineziterapijos veiksmingumą ligoniams, patyrusiems nudegimų traumą.

Metodai. Buvo apžvelgta literatūra. Duomenys surinkti iš duomenų bazių PubMed, ScienceDirect, ClinicalKey. Straipsniai publikuoti tarp 2009 ir 2020 metų. Ieškoma su šiais raktažodžiais: nudegimų trauma, kineziterapija, pratimai, raumenų jèga, reabilitacija. Atrinkti ir išanalizuoti 36 straipsniai, atitinkantys nagrinèjamą temą.

Rezultatai. Vienas iš svarbiausių žingsnių reabilitacijos metu po nudegimų traumos yra pratimai, taikomi atgauti judesių amplitudę sąnariuose, didinti raumenų jègą ir ištvermę, apsaugoti nuo trombembolijų komplikacijų, susigrąžinti fizinę ir psichologinę sveikatą. Kineziterapija taikoma visose nudegimų traumos gydymo fazèse, tačiau nagrinètuose straipsniuose taikomi įvairūs mobilumo, jègos, ištvermès, judesių amplitudès didinimo pratimai. Skausmui mažinti taikomi pratimai pasitelkiant virtualią realybę, diafragminį kvėpavimą ir muzikos terapiją. Kontraktūrų prevencijai taikomas gydymas padètimi ir ịtvarai.

Išvados. Pratimai yra pagrindinè ir saugi kineziterapijos priemonė po nudegimų traumos visais nudegimo traumos gydymo laikotarpiais siekiant padidinti raumenų jègą, pagerinti fizinị pajègumą, bendrą organizmo funkciją, liesają kūno masę, ir neturi neigiamo poveikio hipermetaboliniam atsakui.

Raktažodžiai: nudegimų trauma, kineziterapija, pratimai, raumenų jèga, reabilitacija.

\section{IVADAS}

Nudegimų trauma priskiriama prie labiausiai žalojančių traumų, kokią žmogus gali patirti per savo gyvenimą (Stavrou et al., 2014). Nudegimų traumos gydymas brangus, trunka ilgai ir sukelia ilgalaikius daugelio organizmo sistemų sutrikimus (Young et al., 2017), kontraktūras, randejjimą, skausmą, bendrą viso kūno nusilpimą, pablogèjusią gyvenimo pilnatvę ir psichologinę būklę (Cubitt et al., 2016; Young et al., 2017), sumažèjusi fizinị aktyvumą (Porter et al., 2015). Raumenų masès sumažėjimas dẻl baltymų katabolizmo po nudegimų traumos gali tęstis net

Copyright (C) 2020 Brigita Siparytė-Sinkevičienė, Rytis Rimdeika. Published by Lithuanian Sports University. This is an Open Access article distributed under the terms of the Creative Commons Attribution 4.0 International License, which permits unrestricted use, distribution, and reproduction in any medium, provided the original author and source are credited. 
9-12 mėnesiu po traumos, dèl to padideja sepsio rizika, mirtingumas, gydymo išlaidos, ilgejja atsigavimo ir gydymo laikas (Saeman et al., 2015).

Nudegimų traumos gydymas susijęs su skausmingomis procedūromis, tokiomis kaip žaizdų tvarstymas ir reabilitacija (Scapin et al., 2018). Kontraktūrų prevencijai po nudegimų traumos svarbi kineziterapija, kai taikomi pasyvūs, aktyvūs, jègos ir tempimo pratimai, didinantys pažeistų audinių elastingumą, judesių amplitudę, ištvermę, bendrą organizmo būklę, gerinantys èjimo funkciją (Carrougher et al., 2009). Nustatytas teigiamas pratimų poveikis fiziniam pajègumui ir raumenų jègai (Porter et al., 2015; Flores et al., 2020). Pagrindinis kineziterapijos tikslas yra grąžinti fizini pajègumą ir savarankiškumą (Gittings et al., 2018), tačiau funkcinis atsigavimas gali užtrukti net iki 24 mėnesių po nudegimų traumos (Deeter et al., 2018). Kineziterapijos netaikymas blogina normalu gijimo procesą, didina kontraktūrų išsivystymo, randèjimo ir judesių amplitudès sumažèjimo riziką (Carrougher et al., 2009). Kineziterapijos vaidmuo yra lemiamas nudegimų traumos pasekmių mažinimui (Carrougher et al., 2009). Kineziterapija yra saugi ir efektyvi intervencija, taikoma fiziologinių funkcijų atgavimui po nudegimų traumos, bet nepakankamai ištyrinèta, lyginant su kitomis nudegimų traumos gydymui taikomomis intervencijomis (Flores et al., 2020).

Lietuvoje publikuojamuose žurnaluose nebuvo rasta straipsnių, kuriuose būtų rašoma apie kineziterapiją po nudegimų traumos. Nudegimų trauma ir kineziterapija pasaulyje yra plačiai nagrinejjama tema, kuomet vertinami fizinès, psichinès ir socialinès sveikatos rodikliai. Todẻl išsikèlème tikslą išanalizuoti mokslinę literatūrą apie nudegimų traumos poveikị dažniausiai pažeidžiamoms organizmo sistemoms ir kineziterapijos veiksmingumą ligoniams, patyrusiems nudegimų traumą.

\section{PRATIMAI GYDANT NUDEGIMŲ TRAUMAS}

Pagrindinis su sveikata susijęs rodiklis yra fizinis pajègumas, apibūdinamas kaip geros savijautos būklè su nedidele sveikatos problemų rizika ir gebejjimu būti fiziškai aktyviu. Išskiriami penki su sveikata susiję sveikatos komponentai, reikalingi kasdieniam aktyvumui atlikti: raumenų jèga, raumenų ištvermè, kūno kompozicija, lankstumas, širdies ir kraujagyslių bei kvėpavimo sistemų ištvermė, kurie taip pat susiję su nudegimo traumos rodiklių vertinimo ypatumais (Disseldorp et al., 2011). Fizinio pajègumo sumažèjimas dèl nudegimų traumos yra atvirų žaizdụ, hipermetabolinès būklès, chirurginių intervencijų, medikamentų, ilgai trunkančio gulejimo laikotarpio, kvẻpavimo sistemos pažeidimų, skausmo, psichologinių problemų pasekmè (Disseldorp et al., 2011). 11 mokslinių studijų nustatė dẻl nudegimų traumos mažejantị fizinị pajègumą, bet pritaikyta pratimų programa gerina visus fizinio pajègumo komponentus (Disseldorp et al., 2011). 
Vienas iš svarbiausių žingsnių reabilitacijos metu po nudegimų traumos yra pratimai (Mudawarima et al., 2017; Flores et al., 2018; Yurdalan et al., 2018). Kineziterapija po nudegimų traumos pradedama nuo ligonio patekimo ị gydymo isstaigą, ir tai jau tapo standartiniu gydymu daugelyje pasaulio nudegimų centru (Deng et al., 2016). Pratimai yra svarbūs siekiant atgauti judesių amplitudę sąnariuose, didinti raumenų jègą ir ištvermę, apsaugoti nuo trombembolijų komplikacijų, susigrąžinti fizinę ir psichologinę sveikatą. Dẻl nudegimų traumos ligoniai praleidžia daug laiko nejudèdami, todèl turi būti atliekami aktyvūs ir pasyvūs pratimai tiek ilgai, kiek reikia. Jei gydymas pratimais netaikomas ar pratimų taikymas atidedamas, ligoniai susiduria su neišvengiamomis problemomis: kontraktūromis, randejjimu, heterotopine osifikacija, nuolat didejjančiu minkštujų audinių tempimu (Yurdalan et al., 2018), pakitusiomis biomechaninèmis ypatybėmis, kūno padètimi ir eisena (Mudawarima et al., 2017). Kiti autoriai nurodo skausmą, niežèjimą, temperatūros pokyčių netoleravimą, nuovargị, neurologinius pažeidimus (Kazis et al., 2017), gyvenimo pilnatvès mažejimą (Yurdalan et al., 2018). Nepaisant intensyvios kineziterapijos taikymo, ligoninèje 39\% ligonių, gydomų dẻl nudegimų traumos, vis dar išsivysto randinès kontraktūros (Parry et al., 2015).

Kineziterapija taikoma visose nudegimų traumos gydymo fazèse (Anthonissen et al., 2016; Mudawarima et al., 2017) ir apima ịvairius kineziterapijos metodus pratimus, širdies kraujagyslių ir plaučių sistemų treniravimą, sąnarių mobilizaciją, gydymą padètimi, ịtvarų pritaikymą (Anthonissen et al., 2016). O. Flores'o su bendraautoriais (2018) atlikta sisteminè apžvalga su 27/2253 atrinktais pilnateksčiais straipsniais apie pratimus, gerinančius nudegimo traumos išeitis, nustate pratimu naudą kūno kompozicijai (liemens ir kojų kūno masei), mažesni operacijų poreikị kontraktūrų korekcijai ir pagerèjusią gyvenimo pilnatvę. Visgi nagrinètuose straipsniuose labai skyrèsi taikyti pratimai: aerobiniai, aerobiniai ir jègos, viso kūno vibracija, skirta kojų raumenų jègai didinti, izokinetiniai, jègos ir pusiausvyros, judesių amplitudès ir pratimai taikant virtualią realybę. Dèl tokio pratimu taikymo netolygumo sunku pateikti apibendrintus rezultatus, bet atskiros studijos rodo, kad taikant pratimus gerejo fizinis pajègumas, raumenų jèga, kūno kompozicija, gyvenimo pilnatvè. Kiti autoriai tyrimais nustate, kad trijų savaičių namų programa, taikyta po stacionaraus gydymo, pagerino širdies ir kraujagyslių sistemos pajègumą, liesają kūno masę ir ligonių fizinę, psichologinę ir socialinę sveikatą (Yurdalan et al., 2018).

Ligoniai, dèl nudegimų traumos gydomi intensyvios terapijos skyriuje, susiduria su tokia būkle, kai pasireiškia generalizuotas viso kūno arba tik rankų, ar tik kojų silpnumas. Nèra ir atskiro termino ịvardyti šiam sutrikimui, kuris pasireiškia nuo 2 iki 29\% ligonių, gydomų dèl nudegimų traumos, ir tokia būklè reikalauja ilgalaikès reabilitacijos (Cubitt et al., 2016). Rizikos veiksniai: sisteminis 
uždegiminis atsakas ị nudegimų traumą, sepsis, daugelio organų nepakankamumas, ilgalaikis ventiliacijos poreikis, steroidų, antibiotikų vartojimas. Nustatyta, kad jaunesni ligoniai dažniau susidūrè su šiuo silpnumu nei vyresni (Cubitt et al., 2016). Atliktas tyrimas nustate, kad ligoniams, kuriems nustatytas toks silpnumas, smarkiai skyrèsi gebẻjimo savarankiškai atsisèsti ir vaikščioti laikas, lyginant su tais, kuriems toks silpnumas nebuvo nustatytas (Cubitt et al., 2016). Intensyvios terapijos skyriuose dèl nudegimų traumos gydomiems ligoniams rekomenduojama taikyti kvépavimo ir mobilumo pratimus. Straipsnio autoriai mobilumo pratimus apibūdina kaip pasyvius, aktyvius ar rankų, kojų ir liemens jègos pratimus, padèties keitimą, sodinimą, statymą, jei leidžia būklè - vaikščiojimą (Thais et al., 2020). Ankstyvos kineziterapijos taikymas rekomenduojamas ir mechaniškai ventiliuojamiems ligoniams (Cubitt et al., 2016). Tokių studijų, kai kineziterapija taikoma intensyvios terapijos skyriuose ir vertinamas poveikis funkcinei būklei, nėra daug, bet tyrejjai nustatė teigiamą koreliaciją tarp plaštakos griebimo raumenų jègos ir šešių minučių èjimo testo rodiklių, neigiamą koreliaciją su lovadienių skaičiumi (Thais et al., 2020). Anksčiau atlikti tyrimai nustatè, kad kineziterapija, taikoma intensyvios terapijos skyriuje po nudegimų ir kitų traumų, yra saugus gydymo metodas, mažinantis plaučių uždegimo ir giliujų venų trombozès riziką, bet nesumažina gydymo trukmès ir ventiliacijos poreikio (Clark et al., 2013).

\section{GYDYMAS PADE்TIMI IR NUDEGIMŲ TRAUMA}

Literatūroje nurodama gydymo padetimi taikymas esant nudegimų traumai, kai pakenktai kūno sričiai pritaikoma padètis priešinga kryptimi, nei galimai besiformuojanti kontraktūra (Serghiou et al., 2016). Dẻl susitraukimo jègos poveikio minkštiesiems audiniams žaizdų gijimo metu ligonis linkęs laikyti rankas ir kojas tokios padèties, kuri palanki formuotis kontraktūroms ir deformacijoms. Ligoniai, patyrę $2 \mathrm{~B}^{\circ}-3^{\circ}$ nudegimus, turi didesnę kontraktūrų išsivystymo riziką (Serghiou et al., 2016). Gydymas padètimi pritaikomas taip, kad padètų pasiekti šių tikslų: mažinti edemą; išlaikyti sąnarius taisyklingos, fiziologinès padèties, gerinti žaizdų gijimą ir mažinti kontraktūrų formavimą (Serghiou et al., 2016).

Nèra didelio pasirinkimo straipsnių, analizuojančių gydymo padètimi poveiki rankų ir kojų funkcijai po nudegimų traumos. Daugiausia randama tyrimų, analizuojančiu peties srities nudegimus. Pažasties srities kontraktūros po nudegimų traumos sudaro $20-30 \%$ su nudegimais susijusių kontraktūrų ir smarkiai riboja rankos funkciją (Lester et al., 2013). Norint išvengti tokių kontraktūrų, specialistams yra didelis iššūkis dèl pažasties srities natūralaus anatominio iggaubtumo, apatinès sąnario kapsulès laisvumo, kai ranka užima neutralią, pritrauktą padėtį. Esant pažasties srities nudegimams, rekomenduojama rankos padètis, kai žastas 
atitrauktas ar sulenktas $90^{\circ} \mathrm{kampu}$, siekiant didesnès amplitudės ir mažesnès randinès kontraktūros peties sąnaryje. Didesnè nei $90^{\circ}$ peties sąnario padètis nerekomenduojama dèl neigiamo poveikio peties rezginiui ar padidejusio tempimo rankos periferiniams nervams (Lester et al., 2013). K. U. Jang'as su bendraautoriais (2015) atliko tyrimą ir pritaikè gydymą padètimi bei įtvarą peties sąnariui, kai žastas buvo atitrauktas $90^{\circ} \mathrm{kampu}$, ir nustaté, kad grupè, kuriai buvo pritaikytas toks gydymas, pasiekè geresnių peties sąnario judesių amplitudès rodiklių, lyginant su grupe, kuriai taikyti tik pratimai. Tai pirmas iš nedaugelio atliktų tyrimų, kuriuo gautas teigiamas judesių amplitudès rodiklis. Pritaikant gydymą padètimi, rekomenduojama atsižvelgti ị rizikos ir naudos santykị (Lester et al., 2013). Gydymo padètimi ịrodymų lygmuo yra silpnas ir rekomendacijos daugiausia remiasi patyrusių specialistų praktinèmis įžvalgomis (Serghiou et al., 2016).

Kartu su kitomis terapinėmis priemonėmis kontraktūrų prevencijai rekomenduojami statiniai ịtvarai. Ankstyvoje žaizdų gijimo fazèje statinių ịtvarų naudojimas, manoma, mažina žaizdos ar rando sutrumpejjimą, kai pritaikius įtvarą sukuriamas mechaninis krūvis priešinga kryptimi, nei vyksta žaizdos gijimas (Schouten et al., 2012). Visgi tyrimų, patvirtinančių statinių ịtvarų veiksmingumą, trūksta. Autoriai pateikia ir priešingą nuomonę apie statinių ịtvarų naudojimą teigdami, kad ịtvaru sukuriamas tempimo krūvis didina miofibroblastų aktyvumą bei kontrakcijos riziką randiniame audinyje (Schouten et al., 2012). Tai iliustruoja klinikinis pavyzdys, kai po ilgalaikio ịtvaro dèvèjimo jị pašalinus pastebimas ryškus audinių sutrumpejjimas (Schouten et al., 2012). Manoma, kad reikalingi klinikiniai tyrimai, kurie įvertintu gydymo padètimi poveikį ilgalaikèje perspektyvoje ir sąsajas su funkcijos atsigavimu (Serghiou et al., 2016), îtvarų pritaikymą ūmiuoju nudegimo traumos laikotarpiu kontraktūrų prevencijai ịvertinant, ar jie veiksmingi, ar tik siekiama rezultato (Schouten et al., 2012). Statinių įtvarų nerekomenduojama taikyti, kol nèra pastebimas judesių amplitudės sumažèjimas (Schouten et al., 2012).

\section{RAUMENŲ JÉGOS POKYČIAI PO NUDEGIMŲ TRAUMOS IR KINEZITERAPIJA}

Sunkus nudegimas sukelia atsaką kiekvieno organo sistemoje. Uždegimas, hipermetabolizmas, raumenų jègos, atsparumo insulinui sumažèjimas, patofiziologiniai pokyčiai galimi dèl sunkios nudegimų traumos. Dèl nudegimų traumos išsivystęs baltymų katabolizmas, liesosios kūno masès netekimas ir jị lydintis raumenų jègos sumažèjimas, gali tęstis ir po žaizdų užgijimo praèjus 9-12 mẻnesių ar net keletą metų (Bakhtyar et al., 2015; Saeman et al., 2015; Nielson et al., 2017). C. Porter'is su bendraautoriais (2015) atliko tyrimą su didelès apimties nudegimų traumą patyrusiais suaugusiais ligoniais ir pastebejo sutrikusią mitochondrijų 
funkciją, didėjančią mitochondrijų termogenezę. Nustatyta, kad didelę nudegimų traumą patyrę ligoniai turi mažesnę raumenų jègą ir ištvermę, lyginant su sveikais nenudegusiais suaugusiaisiais (Porter et al., 2015). Ryškus raumenų masės sumažèjimas didina sepsio riziką ir mirtingumą, gydymo išlaidas, ilgina gydymo ir atsigavimo laiką. Judesių apribojimas dèl nudegimų traumos daugumai ligonių sunkina judejjimą ir gali būti siejamas su raumenų atrofijos išsivystymu (Saeman et al., 2015). Raumenų masès ir jègos sumažejimas riboja kasdienį aktyvumą ir galimybę būti fiziškai aktyviu. Jègos pratimų taikymas mažina raumenų atrofiją. Jègos pratimai - tai pratimai, kuriuos atliekant reikia ịveikti išorinị pasipriešinimą. Tokie pratimai didina baltymų sintezę ir raumenų masę (Gittings et al., 2018). Deguonies suvartojimo procesai ir adenozintrifosfato (ATF) gamyba vyksta mitochondrijose, ir metabolizmas gali būti atgaunamas tada, kai taikomos intervencijos, padedančios atgauti mitochondrijų funkciją. Deguonies suvartojimas po nudegimų traumos viršija ATF produkciją. Jègos pratimų atlikimas akivaizdžiai pagerina mitochondrijų funkciją ir ATF gamybą (Bakhtyar et al., 2015). Sveikiems, bet gulintiems tiriamiesiems nuo pirmos nejudèjimo dienos jègos pratimų taikymas apsaugo juos nuo baltymų sintezės raumenyse sumažèjimo (Pavoni et al., 2010). Sisteminejje mokslinių straipsnių apžvalgoje analizuotas jègos pratimų taikymas skirtingu nudegimų traumos gydymo laikotarpiu - iš karto po žaizdų užgijimo ar praejus 6 mènesiems po nudegimų traumos. Jègos pratimų atlikimo intensyvumas progresuoja nuo 60 iki 85\% maksimalaus pakartojimo, dažnumas - 3 kartai per savaitę, trukmé - vienose studijose 6 savaitès, kitose - 12 savaičių (Gittings et al., 2018). Suaugusiems asmenims rekomenduojama 6-12 savaičių pratimų programa, vaikams - 12 savaičių pratimų programa. Daugiau nei 12 savaičių trukmès jègos ir ištvermès pratimų programa nerekomenduojama, nes nèra atlikta tyrimų, kad tokia programa būtų naudinga (Nedelec et al., 2016). A. A. Ebid'as su bendrautoriais (2012) nustatè, kad jègos pratimai (izokinetiniai) pradèti taikyti kojų raumenims 3 kartus per savaitę praejjus 6 ménesiams po nudegimų traumos smarkiai padidina raumenų jègą, lyginant su kontrolinès grupès ligoniais.

Daugumoje apžvelgtų straipsnių teigiama, kad jègos pratimų taikymas nudegimų traumą patyrusiems ligoniams yra nepakankamai ištyrinètas (Pavoni et al., 2010; Gittings et al., 2018). Pratimų taikymas pradedamas jau pasibaigus žaizdų epitelizacijai, ir nèra gausu tyrimų, kurie vertinų funkcijos sutrikimus ir juos parodančius rodiklius ūmioje ar poūmioje žaizdų gijimo fazèje, mažos ir vidutinès nudegimų traumos apimties atvejais (Gittings et al., 2017). Tyrimų atlikimą sunkina tai, kad nudegimų traumą patyrę ligoniai yra heterogeninè populiacija, netolygiai pasiskirsčiusi pagal amžių, traumos mechanizmą, skirtingą pažaidos gylị ir lokalizaciją, sveikatos būklę (Pavoni et al., 2010). Nėra tyrimų, kurie nagrinètų jègos pratimų taikymą ūmiuoju nudegimo traumos laikotarpiu. Autoriai kelia tolesnių 
tyrimų hipotezę, kad ankstyvas jègos pratimų taikymas po nudegimų traumos sumažina raumenų atrofiją (Saeman et al., 2015).

\section{ŠIRDIES IR KRAUJAGYSLIŲ BEI KVĖPAVIMO SISTEMŲ POKYČIAI PO NUDEGIMŲ TRAUMOS IR KINEZITERAPIJA}

Širdies ir kraujagyslių bei plaučių sistemų pajègumas yra svarbus visų mirtingumo priežasčių veiksnys (Rivas et al., 2018). Plaučių funkcijos sutrikimai su aerobinès funkcijos pablogėjimu nustatomi ne visiems nudegimų traumą patyrusiems asmenims. T. L. Grisbrook su bendraautoriais pateikia kitų autorių atliktus tyrimus, kurie nustatè, kad nudegimų traumą patyrę suaugusieji yra žemesnio aerobinio pajègumo ir jiems labiau trūksta deguonies maksimalaus fizinio krūvio metu, lyginant su sveikais suaugusiaisiais. Toks deficitas gali tęstis net iki 5 metu po traumos (Grisbrook et al., 2012; Rivas et al., 2018), bet nekoreliuoja su plaučių funkcija, o sumažėjęs aerobinis pajègumas labiau susijęs su nejudejjimo laikotarpiu ir hipermetaboline būkle po nudegimų traumos (Grisbrook et al., 2012). C. Porter'is su bendraautoriais (2015) teigia, kad didelès apimties nudegimų trauma, ilgalaikis nejudumas, mechaninès ventiliacijos poreikis veikia plaučių funkciją ir yra nustatyta, kad suaugusių nudegimo traumą patyrusių ligonių plaučių funkcija blogesnè, o vaikų forsuota gyvybinė plaučių talpa ir iškvėpimo greitis per 1 sekundę buvo mažesni nei sveikų nenudegusių vaikų. Jau prieš dešimtmeti tyrejjai nustatė, kad esant kvẻpavimo takų nudegimams, ligoniui atliekant fizinį krūvị, ryškesni plaučių ventiliacijos funkcijos sutrikimai nei širdies kraujagyslių sistemos (Grisbrook et al., 2012). Nustatyta, kad po nudegimų traumos galimi obstrukciniai ir restrikciniai plaučių funkcijos sutrikimai (Grisbrook et al., 2012; Björnhagen et al., 2018), pasireiškiantys pablogèjusia reakcija ị fizinį krūvị, kai yra žemas maksimalusis širdies susitraukimų dažnis, nepakankamas deguonies kiekis ir dusulys (Grisbrook et al., 2012). Kiti autoriai nurodo padidejusị bronchų hiperreaktyvumą, kvẻpavimo takų randejjimo išsivystymą ir sutrikusį deguonies transportavimą (Björnhagen et al., 2018). Nustatyta, kad aerobiniai ir jègos pratimai neturejjo ịtakos plaučių funkcijai, bet jų taikymas pagerino aerobini pajègumą ir kasdienį aktyvumą (Grisbrook et al., 2012), o siekiant atgauti plaučių funkciją po nudegimų traumos rekomenduotina taikyti pratimus, didinančius fizini pajègumą (Porter et al., 2015). Aerobiniam pajègumui lavinti daugumoje studijų naudojamas bėgimo takelis ar dviratis (Nedelec et al., 2016), aerobinio krūvio trukmè - nuo 20 iki 30 minučiu (Gittings et al., 2018). Hipermetabolinė būklè po nudegimų traumos veikia ir širdies kraujagysliụ sistemą, kai didejja deguonies suvartojimas, širdies išstūmimo jẻga (Grisbrook et al., 2012; Nielson et al., 2017), minutès ventiliacija ir kūno temperatūra (Grisbrook et al., 2012). Širdies susitraukimų dažnis gali išlikti padidèjęs net iki dvejų metų po 
nudegimų traumos, o padidèjęs energijos suvartojimas po nudegimų traumos veda prie aerobinio pajègumo sumažèjimo (Grisbrook et al., 2012). Jègos ir aerobinių pratimų derinys dažniausiai straipsniuose aprašoma kineziterapijos priemonè po nudegimų traumos (Flores et al., 2020). Jègos ir aerobinių pratimų taikymas po nudegimų traumos padidino raumenų jègą ir ištvermę, liesają kūno masę, aminorūgščiu pasisavinimą raumenyse, lyginant su standartinę kineziterapiją gavusiais ligoniais (Bakhtyar et al., 2015).

\section{SKAUSMAS, NUDEGIMŲ TRAUMA IR NEFARMAKOLOGINĖS GYDYMO PRIEMONĖS}

Nudegimų traumą lydintis komponentas yra skausmas (Li et al., 2017). Klinikineje praktikoje nudegimų skausmas apibūdinamas kaip intensyviausias ir ilgiausiai trunkantis, jis yra susijęs tiek su pačia nudegimų trauma, tiek su gydymo procedūromis (Lončar et al., 2006). Žaizdų gydymas, dažnas jų tvarstymas, reabilitacija ir kitos gydymo metu atliekamos procedūros susijusios su skausmu, stresu ir psichologiniais išgyvenimais (Scapin et al., 2018). Baimė yra dažniausiai nudegimų traumą patyrusių ligonių ịvardijama emocija (Li et al., 2017). Nustatyta, kad baimè didina ūmų skausmą, o baimè ir depresija susijusios su aukštesniais skausmo intensyvumo balais. Negydomas skausmas sunkina gydymą, ligonio priežiūrą, ilgainiui gali vystytis lètinis skausmo sindromas (Lončar et al., 2006). Teigiama, kad gydant nudegimo traumas reikalingas holistinis požiūris ị skausmo ir baimès gydymą ( $\mathrm{Li}$ et al., 2017). Tokie nefarmakologiniai gydymo būdai kaip hipnozè, kognityvinè elgesio terapija, atsipalaidavimo technikos, muzikos terapija, istorijų pasakojimas reikšmingi skausmo mažinimui (Scapin et al., 2018). Klinikinejje praktikoje medicininių procedūrų metu seniai taikomas metodas skausmui ir baimei gydyti yra muzikos terapija, jos poveikis grindžiamas skausmo vartu teorija. Neseniai nustatyta, kad muzikos terapija keičia skausmo pojūtị per du skirtingus mechanizmus, kurie susiję su gama ir delta smegenų bangų aktyvumo kitimu esant skirtingai skausmo būklei (Li et al., 2017). J. Li su bendraautoriais apibendrina kitu autorių atliktus tyrimus, kuriuose nustatyta, kad muzikos terapija sumažino mechaniškai ventiliuojamų ir gydomų intensyvios terapijos skyrių ligonių baimę, ir padeda sumažinti pooperacinị skausmą, baimę ir analgetikų poreikị, pagerina ligonių pasitenkinimo jausmą atsigavimo laikotarpiu. Studijos, nagrinejjančios muzikos terapijos poveiki nudegimų traumai, radosi nuo 1970 metu. Nustatyta, kad muzikos terapijos taikymas žaizdų tvarstymo metu teigiamai veikia skausmo mažejimą, ypač nedidelio (Li et al., 2017). Kiti autoriai nustatė, kad muzikos terapija sumažino baimę ir padejjo atsipalaiduoti tiriamiesiems žaizdų tvarstymo procedūru metu (Li et al., 2017). J. Li su bendraautoriais (2017) pateikè išvadą, kad yra tei- 
giama koreliacija tarp muzikos terapijos taikymo ir nudegimų traumą patyrusių ligonių, skausmo, baimès, širdies susitraukimų dažnio sumažèjimo, tačiau aprašo ir kitų tyrejų tyrimo rezultatus, kuriuose teigiama, kad relaksacinės muzikos taikymas atliekant judesių amplitudès didinimo pratimus skausmo intensyvumo ir baimès nesumažino. Kitas panašus tyrimas atliktas C. Porter'io su bendraautoriais (2015) - jie teigia, kad muzikos terapija, kartu taikant ir kineziterapiją, labiau pagerino jaunesnių nei 7 metai vaikų judesių amplitudę alkūnès ir kelio sąnariuose, nei tų, kuriems taikyta tik kineziterapija.

Kita nesudètinga ir seniai naudojama atsipalaidavimo technika stresui mažinti yra diafragminis kvejpavimas. Tokio kvėpavimo metu mažeja įtampa, neuroraumeninis aktyvumas, sumažeja simpatinès nervų sistemos aktyvumas ir smegenų žievès jaudrumas. E. Park'as su bendraautoriais (2013) vertino relaksacinio / diafragminio kvėpavimo ir nuskausminamųjų vaistų vartojimo derinị skausmui ir baimei ịvertinti žaizdų tvarstymo procedūrų metu ir nustatė, kad toks kvėpavimas gali padèti sumažinti skausmą ir baimę.

Technologijų augimas gydant nudegimų traumas leidžia panaudoti virtualią realybę, kuri kaip ir kitos nefarmakologinès gydymo technikos remiasi distrakcija, pasižymi skausmą, baimę ir depresijos simptomus mažinančiu poveikiu. Virtualios realybès poveikis skausmo mažinimui tyrinèjamas nuo 2000 metų. Virtuali realybė sukuriama naudojat vaizdo žaidimus ar įrenginius, kurie sukuria trimatę erdvę. Būtent šių ịrenginių pritaikymas turi įtakos skausmo sumažèjimui. Aptiktos 9 mokslinès studijos, kuriose buvo taikytas virtualios realybės ir vaistų nuo skausmo vartojimo derinys, ir jos nustate skausmo ir baimès sumažèjimą (Scapin et al., 2018). Pastebetas ir mažesnis vaistų nuo skausmo poreikis. Kitose studijose, kuriose taikyta virtuali realybė, pastebėta, kad ligoniai mažiau galvojo apie skausmą, buvo mažesnis skausmo intensyvumas ir lengviau tvarstomos žaizdos, atliekama kineziterapija (Scapin et al., 2018). Studijos, atliktos analizuojant magnetinio rezonanso vaizdus, nustate, kad skausmas generuojamas penkiose galvos smegenų zonose esant skausmingiems stimulams (Scapin et al., 2018). Taikant virtualią realybę, smarkiai sumažejo aktyvumas šiose galvos smegenų zonose. Viename moksliniame straipsnyje buvo analizuojami kontrolinès ir tiriamosios grupès, kuriai buvo taikyta virtuali realybė, judesių amplitudès pokyčiai atliekant pratimus. Pokyčiu nebuvo nustatyta, bet virtualios realybės grupejje skausmo intensyvumas pratimu metu buvo mažesnis (Scapin et al., 2018). Vaizdo žaidimų taikymas padidina dopamino išsiskyrimą ir silpnina skausmo receptorių veikimą, sumažindami skausmo pojūtį (Parker et al., 2016). Manoma, kad mažesnis skausmas sumažina baimę ir leidžia mažiau saugotis atliekant judesius. Vaizdo žaidimų taikymas ūmiuoju nudegimų traumos laikotarpiu labiau sumažino skausmą, lyginant su ịprastų pratimų programa, ypač tiems ligoniams, kurie turèjo didesnị skausmą tyrimo pradžioje 
(Parker et al., 2016). I. Parry'is su bendraautoriais (2015), palyginę vaizdo žaidimu grupę su standartine reabilitacijos grupe, nustatè, kad abiejų grupių rodikliai buvo lygiaverčiai vertinant judesių amplitudès atsigavimą 3 savaičių, 3 ir 6 mėnesių laikotarpiais, bet skausmas atliekant judesius buvo mažesnis vaizdo žaidimų grupeje.

Apžvelgiant keleto autorių nuomonę, virtuali realybẻ gali būti taikoma kaip papildoma priemonè, gerinanti nudegimų traumos gydymo rezultatus ir sumažina skausmą (Parry et al., 2015; Scapin et al., 2018), o muzikos terapijos taikymas teigiamai veikia skausmo ir baimès, širdies susitraukimų dažnio sumažèjimą ( $\mathrm{Li}$ et al., 2017).

\section{REZULTATŲ APTARIMAS}

Kineziterapija po nudegimų traumos plačiai taikoma siekiant sumažinti nudegimu traumos sukeltas pasekmes (Flores et al., 2020). B. Nedelec'as su bendraautoriais (2016) nustatė aerobinių ir jẻgos pratimų teigiamą poveikị aerobiniam pajègumui, liesajai kūno masei, raumenų jègai, o S. U. Yurdalan'as su bendraautoriais (2018) įrode, kad namų programa padidino širdies ir kraujagyslių sistemos pajègumą bei liesają kūno masę. Pratimų veiksmingumas ir saugumas buvo irodyti dviejose sisteminèse apžvalgose (Nedelec et al., 2016; Flores et al., 2018) ir vienoje metaanalizèje (Gittings et al., 2018). H. Deng'as su bendraautoriais (2016), vertindami ligonius, dèl nudegimų traumos besigydančius intensyvios terapijos skyriuose, nustate, kad mobilumo treniravimas sumažino dienų skaičių, praleistų intensyvios terapijos skyriuje, gydymo trukmę, griežtą nejudẻjimo laiką po traumos ir pagerino pažeistų sąnarių judesių amplitudę, tačiau pastebejjo, kad trūko reabilitacijos personalo ir yra nepakankamas suvokimas apie ankstyvosios reabilitacijos naudą Kinijoje. Nepaisant atliktų tyrimų O. Flores'as su bendraautoriais (2018) teigia, kad nèra pakankamai studijų, kurios tyrinètų pratimų poveikị uždegimo ir metaboliniams rodikliams, plaučių funkcijai, skausmui ir judesių amplitudès pokyčiams. P. Gittings'as su bendraautoriais (2018) teigia, kad reikia toliau tęsti tyrimus vertinat pratimų poveikị tiek vaikams, tiek suaugusiesiems, ịtraukiant gyvenimo pilnatvès, grịžimo ị darbą ar aktyvią veiklą po traumos rodiklius, o B. Nedelec'as su bendraautoriais (2016) siūlo vertinti ir rekonstrukcinès chirurgijos poreikio dažnumą. Nagrinètuose straipsniuose skiriasi laikotarpis, kada pradedami taikyti pratimai. B. Nedelec'as ir kt. (2016) teigia, kad pratimai taikomi skirtingais žaizdų gijimo laikotarpiais - iš karto po stacionaraus gydymo arba praejus 6 mènesiams po nudegimų traumos.

Nors mokslinis įrodymų lygmuo gydymo padètimi yra silpnas, ši priemonè taikoma gydant nudegimų traumas (Serghiou et al., 2016). M. A. Serghiou'as su bendraautoriais (2016) teigia, kad nudegimų specialistai palaiko gydymo padèti- 
mi naudojimą kontraktūrų prevencijai, bet reikalingi tolesni tyrimai klinikiniams stebejjimams pagrịsti. H. J. Shouten'as ir kt. (2012) teigia, kad nesant pakankamai mokslinių įrodymų įtvarų taikymui po nudegimų traumos būtini tyrimai, kurie palygintų įtvarų pritaikymą ir jų netaikymą, vertintų kontraktūrų susiformavimą.

Pastebimas didesnis domejjimasis ir skausmo gydymu (Li et al., 2017). Jis neišvengiamas gydant nudegimų traumas. S. Scapin'as su bendraautoriais (2018) teigia, kad skausmas taikant virtualią realybę sumažèjo ir priklauso nuo taikomos virtualios realybės formos, populiacijos ar taikymo momento - žaizdų tvarstymo ar kineziterapijos procedūrų metu. Daugelis studijų parodè, kad muzika teigiamai veikia skausmo sumažèjimą ( $\mathrm{Li}$ et al., 2017). J. Li su bendraautoriais teigia, kad būtina pateikti standartizuotą muzikos terapijos protokolą atliekant skirtingas gydymo procedūras. Pastebètas ir netolygumas tarp populiacijos, muzikos parinkimo ir atliekamų procedūrų (Li et al., 2017).

Nudegimų trauma pažeidžia daugelị organizmo sistemų, todèl ir kineziterapija po nudegimų traumos apima ịvairių pratimų taikymą skirtingoms klinikinėms situacijoms spręsti. Vieni autoriai moksliniuose straipsniuose tyrinejja raumenų jègos sumažejimą ir jègos pratimų poveikị, kiti širdies ir kraujagyslių, plaučių sistemų pakenkimus ir aerobinių pratimų poveikį, bet yra tyrimų, kurių metu taikomas jègos ir aerobinių pratimų derinys, vertinamas jų veiksmingumas. Minètina, kad yra straipsnių, kuriuose nebuvo nurodyta, kokie pratimai buvo taikyti tyrime. Lietuvoje kol kas nèra mokslinių tyrimų apie kineziterapijos veiksmingumą po nudegimų traumos, todèl galima remtis kitų mokslininkų pateikiamomis išvadomis ir savo klinikine patirtimi, kuri sutampa su pateiktomis rekomendacijomis.

\section{IŠVADOS}

1. Pratimai yra pagrindinè ir saugi kineziterapijos priemonè po nudegimų traumos norint pagerinti raumenų jègą, fizini pajègumą, bendrają organizmo funkciją, liesają kūno masę ir neturi neigiamo poveikio hipermetaboliniam atsakui.

2. Kontraktūru prevencijai rekomenduojama taikyti gydymą padètimi, nors mokslinis įrodymų lygmuo yra silpnas. Statinių įtvarų nerekomenduojama taikyti, kol nèra pastebimas judesių amplitudès sumažèjimas.

3. Skausmui ir baimei mažinti kaip papildoma priemonè gali būti taikoma muzikos terapija, diafragminis kvèpavimas, virtuali realybė, vaizdo žaidimai.

Finansavimas: nèra.

Interesų atskleidimas: nėra. 


\section{LITERATŪRA}

Anthonissen, M., Daly, D., Janssens, T., Kerckhove, E. (2016). The effects of conservative treatments on burn scars: A systematic review. Burns, 42, 508-518.

Bakhtyar, N., Sivayoganathan, T., Jeschke, M. G. (2015). Therapeutic approaches to combatting hypermetabolism in severe burn injuries. Journal of Intensive and Critical Care, 1 (6).

Björnhagen, V., Schüldt Ekholm, K., Larsen, F., Ekholm, J. (2018). Burn survivors pulmonary and muscular impairment, exercise tolerance and return to work following medical vocational rehabilitation: along term follow up. Journal of Rehabilitation Medicine, 50, 465-471.

Carrougher, G. J., Hoffman, H. G., Nakamura, D. et al. (2009) The effect of virtual reality on pain and range of motion in adults with burn injuries. Journal of Burn Care \& Research, 30 (5), 785-791.

Clark, D. E., Lowman, J. D., Griffin, R. L., Matthews, H. M., Reiff, D. A. (2013). Effectiveness of an early mobilization protocol in a trauma and burns intensive care unit: A retrospective cohort study. Physical Therapy, 93 (2), 186-196.

Cubitt, J. J., Davies, M., Lye, G., Evans, J. et al. (2016). Intensive care unit-acquired weakness in the burn population. Journal of Plastic, Reconstructive \& Aesthetic Surgery, 69, 105-109.

Deeter, L., Seaton, M., Carrougher, G. J. et al. (2018). Hospital-acquired complications alter quality of life in adult burn survivors: Report from a burn model system. Burns. Retrieved from https://doi.org/10.1016/j. burns.2018.10.010.

Deng, H., Chen, J., Li, F. et al. (2016). Effects of mobility training on severe burn patients in BICU: A retrospective cohort study. Burns, 42, 1404-1412.

Disseldorp, L. M., Nieuwenhuis, M. K., Van Baar, M. E., Mouton, L. J. (2011). Physical fitness in people after burn injury: A systematic review. Archives of Physical Medicine and Rehabilitation, 92 (9), 1501-1510.

Ebid, A. A., Omar, M. T., Abd El Baky, A. M. (2012). Effect of 12-week isokinetic training on muscle strength in adult with healed thermal burn. Burns, 38 (1), 61-68.

Flores, O., Tyack, Z., Stockton, K., Ware, R., Paratz, J. D. (2018). Exercise training for improving outcome postburns: A systematic review and meta-analysis. Clinical Rehabilitation, 32 (6), 734-746.

Flores, O., Tyack, Z., Stockton, K., Ware, R., Paratz, J. D. (2020). The use of exercise in burns rehabilitation: A Worldwide survey of practice. Burns, 46, 322-332.

Gittings, P., Grisbrook, T., Edgar, D. et al. (2018). Resistance training for rehabilitation after burn injury: A systematic literature review \& meta-analysis. Burns, 44 (4),731-751.

Grisbrook, T. L., Wallman, K. E., Elliott, C. M. et al. (2012). The effect of exercise training on pulmonary function and aerobic capacity in adults with burn. Burns, 38, 607-613.

Jang, K. U., Choi, J. S., Mun, J. H. et al. (2015). Multi-axis shoulder abduction splint in acute burn rehabilitation: A randomized controlled pilot trial. Clinical Rehabilitation, 29 (5), 439-446.

Kazis, L. E., Marino, M., Ni, P. et al. (2017). Development of the life impact burn recovery evaluation (LIBRE) profile: Assessing burn survivors' social participation. Quality of Life Research, 26, 2851-2866.

Lester, M. E., Hazelton, J., Dewey, W. S. et al. (2013). Influence of Upper Extremity Positioning on Pain, Paresthesia, and Tolerance: Advancing Current Practice. Journal of Burn Care \& Research, 34, 342-350.

Li, J., Zhou, L., Wang, Y. (2017). The effects of music intervention on burn patients during treatment procedures: A systematic review and meta-analysis of randomized controlled trials. BMC Complementary and Alternative Medicine, 17, 158.

Lončar, Z., Braš, M., Mičkovic, V. (2006). The Relationships between burn pain, anxiety and depression. Collegium Antropologicum, 30 (2), 319-325.

Mudawarima, T., Chiwaridzo, M., Jelsma, J., Grimmer, K., Muchemwa, F. C. (2017). A systematic review protocol on the effectiveness of therapeutic exercises utilised by physiotherapists to improve function in patients with burns. Systematic Reviews, 6 (207).

Nedelec, B., Parry, I., Acharya, H. et al. (2016). Practice Guidelines for cardiovascular fitness and strengthening exercise prescription after burn injury. Journal of Burn Care \& Research, 37, 539-558.

Nielson, C. B., Duethman, N. C., Howard, J. M. et al. (2017). Burns: Pathophysiology of systemic complications and current management. Journal of Burn Care \& Research, 38 (1), e469-481.

Park, E., Oh, H., Kim, T. (2013). The effects of relaxation breathing on procedural pain and anxiety during burn care. Burns, 39, 1101-1106. 
Parker, M., Delahunty, B., Heberlein, N. et al. (2016). Interactive gaming consoles reduced pain during acute minor burn rehabilitation: A randomized, pilot trial. Burns, 42 (1), 91-96.

Parry, I., Painting, L., Bagley, A. et al. (2015). A pilot prospective randomized control trial comparing exercises using videogame therapy to standard physical therapy: 6 months follow-up. Journal of Burn Care \& Research, 36, 534-544.

Pavoni, V., Gianesello, L., Paparella, L., Tadini Buoninsegni, L., Barboni, E. (2010). Outcome predictors and quality of life of severe burn patients admitted to intensive care unit. Scandinavian Journal of Trauma, Resuscitation and Emergency Medicine, 18, 24.

Porter, C., Hardee, J. P., Herndon, D. N., Suman, O. E. (2015) The role of exercise in the rehabilitation of patients with severe burns. Exercise and Sport Sciences Reviews, 43 (1), 34-40.

Rivas, E., Sanchez, K., Cambiaso-Daniel, J. et al. (2018). Burn injury may have age-dependent effects on strength and aerobic exercise capacity in males. Journal of Burn Care \& Research, 39 (5), 815-822.

Saeman, M. R., DeSpain, K., Liu, M. M. et al. (2015). Effects of exercise on soleus in severe burn and muscle disuse atrophy. Journal of Surgical Research, 198, 19-26.

Scapin, S., Echevarría-Guanilo, M. E., Boeira Fuculo Junior, P. E. R. et al. (2018). Virtual reality in the treatment of burn patients: A systematic review. Burns, 44, 1403-1416.

Schouten, H. J., Nieuwenhuis, M. K, van Zuijlen, P. P. M. (2012). A review on static splinting therapy to prevent burn scar contracture: Do clinical and experimental data warrant its clinical application? Burns, 38, 19-25.

Serghiou, M. A., Niszczak, J., Parry, I., Richard, R. (2016). Clinical practice recommendation for positioning of the burn patient. Burns, 42, 267-275.

Stavrou, D., Weissman, O., Tessone, A. et al. (2014). Health related quality of life in burn patients - A review of the literature. Burns, 40, 788-796.

Thaís Borgheti de Figueiredo, Key Fujisaki Utsunomiya, Amanda Maria Ribas Rosa De Oliveira, Ruy Camargo Pires-Neto, Clarice Tanaka. (2020). Mobilization practices for patients with burn injury in critical care. Burns, 46, 314-321.

Young, A., Brookes, S., Rumsey, N., Blazeby, J. (2017). Agreement on what to measure in randomised controlled trials in burn care: Study protocol for the development of a core outcome set. BMJ Open, 7 (6), e017267.

Yurdalan, S. U., Ünlü, B., Seyyah, M. et al. (2018). Effects of structured home-based exercise program on depression status and quality of life in burn patients. Burns, 44 (5), 1287-1293.

\title{
PHYSIOTHERAPY IN THE TREATMENT OF BURN INJURY. LITERATURE REVIEW
}

\author{
Brigita Siparytė-Sinkevičiene $\dot{e}^{1,2}$, Rytis Rimdeika ${ }^{1,2}$ \\ Hospital of Lithuanian University of Health Sciences Kauno Klinikos ${ }^{I}$ \\ Medical Academy of Lithuanian University of Health Sciences ${ }^{2}$
}

\section{ABSTRACT}

Background. The incidence of burns is associated with a long period of treatment and disability. Burn trauma due to a hypermetabolic response impairs many bodily functions and manifests itself in a decrease in muscle mass and muscle strength, the development of contractures. The application of physiotherapy has been found to increase physical capacity, muscle strength, improve body composition and quality of life. 
Aim. The aim of the study was to analyse the scientific literature on the effects of burn trauma on various body systems and efficacy of physiotherapy in patients with burn injury.

Methods. Literature review of was carried out. Data were collected from databases PubMed, ScienceDirect, ClinicalKey. Articles published between 2009 and 2020 were searched with the following keywords: burn injury, physiotherapy, exercises, muscle strength, rehabilitation. Thirty-six articles related to the topic were selected and analysed.

Results. One of the most important steps in rehabilitation after a burn injury is exercises used to restore the range of movements in the joints, increase muscle strength and endurance, prevention of thromboembolic complication, restore physical and psychological health. Physiotherapy is applied in all phases of the treatment of burns, but the exercises used in the examined articles are diverse: exercises to increase mobility, strength, endurance, range of motion. Exercises with virtual reality, diaphragmatic breathing and music therapy are used to reduce pain. Prevention of contractures includes treatment with position and splints.

Conclusion. Exercises is the main and safe physiotherapy tool in all periods after a burn injury treatment to improve muscle strength, physical capacity, overall body function, lean body mass, and does not adversely affect the hypermetabolic response.

Keywords: burn injury, physiotherapy, exercises, muscle strength, rehabilitation.

Gautas 20200809

Priimtas 20201006 